\title{
4721 SAYILI TÜRK MEDENİ KANUNUMUZA GÖRE AÇILAN TENKİS DAVASI İLE MİRASÇILARIN AÇABİLECEĞİ \\ DİĞER DAVALARIN KARŞILAŞTIRILMASI
}

\author{
Dr. Remzi DEMİR
}

\begin{abstract}
ÖZET
Miras hukukuna göre, gerçek bir kişinin malvarlığı, onun ölümü ile bir bütün olarak kanunun belirlediği veya mirasbırakan tarafından atanmış mirasçılara geçmektedir. Yasal mirasçılar, bazı durumlarda mirasbırakanın ölüme bağlı tasarruflarına veya karşılıksız sağlararası kazandırmalarına karşı, 4721 sayılı Türk Medeni Kanunu'nun Miras Kitabı'nda öngörülen hakları kullanabilirler. Tenkis davası, genel olarak mirasbırakanın tasarruf özgürlüğü sınırlarını aşması durumunda, saklı paylı mirasçılarının başvurabileceği bir yoldur. Mirasbırakanın yapmış olduğu kazandırmalar sonucu, saklı payları ihlal edilmiş olan mirasçılar, tenkis davası açabilecekleri gibi, kendilerine karşı açılmış bir davada tenkis defini de ileri sürebilirler. Mirasta denkleştirme, mirasbırakanın sağlığında, yasal mirasçısına miras payına mahsuben yaptığ karşılıksız kazandırmaların, mevcutsa aynen, değilse değerinin miras ortaklığına geri verilmesi veya kazandırmayı alan mirasçının miras payına mahsup edilmesidir. Denkleştirme müessesesinin amac1, mirasbırakandan sağlararası karşılıksız bir kazandırma almış olan mirasçının, böyle bir kazandırma almamış olan mirasçılara nazaran daha elverişli bir durumda olmasını önlemek ve mirasın paylaşılmasında yasal mirasçılar arasında eşitliği ve hakkaniyeti sağlamaktır . Mirasçı, mirasbırakanın ölümünden sonra el konmuş olan terekedeki parayı ve eşyayı kendi mirasçılık sıfatına dayanan miras sebebiyle istihkak davası ile geri ister. Çalışmamızda, tenkis davasıyla sıkça karıştırılan denkleştirme davası, miras sebebiyle istihkak davası ve ölüme bağlı tasarrufun iptali davası arasındaki farklılıklar, öğretideki görüşler ve Yüksek Yargı kararları ile ayrıntılı biçimde incelenmiştir.
\end{abstract}

Anahtar Kelimeler: Miras Hukuku, Denkleştirme, Tenkis Davası, Saklı Pay, Saklı Paylı Mirasçı, Sağlararası Kazandırma, Miras Sebebiyle İstihkak Davası.

\footnotetext{
* Ankara Batı Cumhuriyet Savcıs1, remzidemir60@hotmail.com, ORCID ID: 0000-0001-6025-5476 (Geliş Tarihi: 15.10.2019 - Kabul Tarihi: 27.11.2019).
} 


\title{
THE COMPARISON BETWEEN THE LAWSUIT OF ACTION BY REDUCTION FILED ACCORDING THE TURKISH CIVIL LAW NUMBERED 4721 AND THE OTHER LAWSUITS THAT CAN BE FILED BY HEIRS
}

\begin{abstract}
According to the law of inheritance, the estate of a real person passes plenary through with his death to the inheritors which has been determined by the law or the testator. In some cases legal heirs may exercise the rights provided by the Turkish Inheritance Civil Code No. 4721, against the testamentary legal disposition or unrequited benefits done by the testator. Action for reduction is a legal right in which the legal heirs with reserved portion may exercise in the event that the testator exceeds the limits of his freedom to dispose of saving in general. As a result of testator's unrequited benefits, the inheritors whose reserved portions have been breach can open the case of action for reduction, as well as making of plea in a case against them. Hotchpot in heritage, is the returning of gratuitous savings to the account of heritage share of his/her legal inheritor in legator's life in kind if any, if not its equivalent value to heritage partnership or deducting the saving from the heritage share of legator. The purpose of the hotchpot mechanism is to prevent legator taken a gratuitous saving from the inheritor to be in a more convenient position when compared to legators having no such saving and to provide equality and justice among legal inheritors. The heir, after the death of the inheritor, seized the money and the property confiscated after the death of the inheritance based on the title of inheritance because of the request for recall. In our study, the differences between the case of equilibrium, the inheritance due to inheritance and the cancellation of death-related savings, which are frequently confused with the criticism case, are examined in detail with the opinions in the doctrine and the decisions of the High Judiciary.
\end{abstract}

Keywords: Inheritance Law, Action for Reduction, Forced Portion, Forced Heir, Inter Vivos Disposition, Hotchpot, Replevin Action Based Upon Inheritance. 


\section{GENEL OLARAK}

Miras hukuku, medeni hukukun en zor kavranan, en karmaşık dallarından birisidir. Dehşet verici ve her canlının mutlaka tadacağı ölüm olayının kaçınılmazlığı ile çirkin miras kavgalarının sıkça rastlanılırlığı da göz önüne alındığında, miras hukuku ilk bakışta soğuk ve itici bir hukuk dalı gibi görünür. $\mathrm{Bu}$ görünümüne rağmen, miras hukukunun, medeni hukukun en hareketli ve hararetli alanlarından biri olması özelliği ile miras hukukçusunun, medeni hukukun hem akrobatı hem de teknokratı olmak zorunda olduğu aşikardır. ${ }^{1}$

Miras hukuku, bütün diğer medeni hukuk dallarının merkezini oluşturduğu gibi, kişiler hukukunun ve aile hukukunun içeriğini, hak sahipliğini sürdürerek, eşya hukukunda yer alan mülkiyet hukukunun da düzenlenmesine katkıda bulunur. ${ }^{2}$ Zira, bir kimse ölünce, malvarlığında yer alan haklar ve borçlar dağıtılmaksızın, bir bütün olarak, bir veya birden fazla kişiye intikal eder. Ölüm sonucunda sadece malvarlığı sahibi değişir. ${ }^{3}$ Işte bu değişim için, medeni hukukun bütün dalları seferber olur.

Mirasbırakanın yaptığı bazı ölüme bağlı ve sağlararası kazandırmaların, saklı payları ihlal ettikleri ya da tasarruf oranını aştıkları oranda etkisizleştirilmeleri, eğer henüz ifa edilmemişlerse, mirasçıların bunları ifa borcundan kurtulması ve şayet ifa edilmişlerse bu oranda iadelerini sağlayan yenilik doğurucu nitelikteki davaya, tenkis davası adı verilmektedir. ${ }^{4} \mathrm{Bu}$ nedenle,

Serozan, Rona / Engin, Baki İlkay ( 2018 ) Miras Hukuku, 5. Baskı, Ankara, Seçkin, s. 5.

Göktürk, Hüseyin Avni ( 1937 ) Miras Hukuku, Ankara, Devlet Basımevi, s. 4.

Kocayusufpaşaoğlu, Necip ( 1987 ) Miras Hukuku, 3. Bası, İstabul, Filiz Kitapevi, s. 3; Gönensay, Samim /Birsen, Kemaleddin ( 1956 ) Miras Hukuku, İstanbul, Fakülteler Matbaasi, s. 1; Eren, $\quad$ Fikret (2016) "Miras Sebebiyle İstihkak Davası", Marmara Üniversitesi Hukuk Fakültesi Hukuk Araştırmaları Dergisi, Prof. Dr. Cevdet Yavuz'a Armağan, C. 22, Sa. 3, s. 1046; Tandoğan, Haluk (1995) 'Miras Sebebiyle İstihkak Davası", Ankara Üniversitesi Hukuk Fakültesi Dergisi, C: 12, S: 1-2, s. 268.

4 İnan, Ali Naim / Ertaş, Şeref / Albaş, Hakan ( 2019 ) Miras Hukuku, 10. Bası, Ankara, Seçkin Yayınevi, s. 387; İmre, Zahit / Erman, Hasan ( 2017 ) Miras Hukuku, 13. Basım, İstanbul, Der Yayınları, s. 261; Dural, Mustafa / Öz, Turgut ( 2015 ) Türk Özel Hukuku - Cilt IV - Miras Hukuku, 8. Bası, İstanbul, Filiz Kitabevi, s. 275; Öztan, Bilge ( 2018 ) Miras Hukuku, 9. Baskı, Ankara, Turhan Kitabevi, s. 113; Nar, Ahmet (2016) Türk Miras Hukukunda Tenkis, İstanbul, Oniki Levha Yayıncılık, s. 14; Özdoğan, Nurcihan Dalcı ( 2017 ) " Sağlararası Kazandırma Konusu Taşınmazların Tenkisi", İnönü Üniversitesi Hukuk Fakültesi Dergisi, C: 8, S: 7, s. 364; Başara, Gamze Turan ( 2016 ) "Ölüme Bağlı Tasarrufların Tenkisi ve Tenkis Davası", Türkiye Adalet Akademisi Dergisi, C: 7, S: 27, s. 388 (Tenkis);

Yavuz, Cevdet (1986) "Miras Hukukunda Tenkisten Sonra Tenkis Konusu Geri Verme (İade) Yükümlülügü", İstanbul Üniversitesi Hukuk Fakültesi Dergisi, C: LI. S: 1, s. 266; Öztürkler, Cemal (2004) Mirasta Denkleştirme, Ankara, Seçkin, s.147; Tüfek, K. Gültekin (1977) Miras Hukukunda Tenkis ve İade Davaları, Ankara, Olgaç Matbaası, s. 102.Ayan, Mehmet (2016) Miras Hukuku, 9. Baskı, Ankara, Seçkin, s. 218; Hatemi, Hüseyin (2018), Miras Hukuku, 8. Baskı, İstanbul, Onikilevha, s. 53; Kılıçoğlu, Ahmet M. ( 2018 ) Miras Hukuku, 9. Bası, Ankara, Turhan Kitabevi, s. 247; Uyar, Talih (1971) "Uygulamada Tereddüt ve İhtilaf Konusu Olan Üç Müessese: Mirasta Tenkis -İptal ve İade", Ankara Barosu Dergisi, S: 3, s. 406; Özuğur, Ali İhsan (2016) Miras Hukuku, 4. Baskı, Ankara, Seçkin, s. 470; Sarı, Suat (2018) Miras Hukuku, 7. Baskı, İstanbul, Filiz Kitabevi, s. 95; Ruhi, Canan / Ruhi, Ahmet Cemal (2015) Ölüme Bağlı Tasarruflar ve İptali, Ankara, Seçkin, s. 46; Antalya, O. Gökhan (2015) Miras Hukuku, 3. Baskı, İstanbul, Legal, s. 291; Genç- 
mahkemece tenkis davasının kabulüne dair verilecek karar, mirasbırakanın öldüğü tarihe kadar geriye yürür ( ex tunc ). ${ }^{5}$ Mirasbırakanın iradesi ile bertaraf edilemeyen bu koruma, mirasbırakanın saklı payı ihlal eden kazandırmalarının, tasarruf özgürlüğü sınırına çekilmesini sağlar. Bu nedenle tenkis talebi, saklı payın yaptırımıdır. ${ }^{6} 4721$ sayılı TMK. ( buradan itibaren TMK. olarak kısaltılacaktır ) ile pek çok miras hukuku terimi sadeleştirildiği halde, tenkis terimi aynı kalmıştır. Sözlük anlamı 'indirim' demek olan tenkis, mirasbırakanın tasarruf oranını aşan kazandırmalarına karşı başvurulacak yolların, yapılacak işlemlerin ve sonuçların bir araya geldiği çerçeve bir kavramdır.

4721 sayılı TMK.'nın m. 505 hükmüne göre; " mirasçı olarak altsoyu, ana ve babası veya eşi bulunan mirasbırakan, mirasının sakl paylar dışında kalan kısmında ölüme bağlı tasarrufta bulunabilir. Bu mirasçılardan hiçbiri yoksa, mirasbırakan mirasının tamamında tasarruf edebilir." denilerek, mirasbırakanın yapmış olduğu sağlararası veya ölüme bağlı tasarruflarıyla tasarruf edebileceği kısmı aşıp aşmadığının belirlenebilmesi için, tasarruf özgürlüğü miktarının belirlenmesi zorunluluktur. ${ }^{8}$ Türk hukukunda yasal mirasçılığın mı yoksa tasarruf özgürlügüüün mü üstün olduğu konusunda, esas olanın yasal mirasçıllk olduğu belirtilmiştir. Gerçekten de, kanun koyucunun sistematiğinde ilk olarak yasal mirasçılık hükümleri, daha sonra da tasarruf özgürlügü düzenlenmiştir. Ayrıca, miras hukukumuz ailenin korunmasına dayalı bir ilkeye sahip olduğu için, üstün tarafın yasal mirasçılık olduğu isabetle vurgulanmıştır.

Tenkis davasının konusu, TMK m. 560/1 hükmünde belirtilmiştir. Bu hükme göre, "Saklı paylarının karşıllı̆ın alamayan mirasçılar, mirasbırakanın tasarruf edebileceği kısmı aşan tasarruflarının tenkisini dava edebilirler." TMK'nın m.565 hükmünde ise, dört bent halinde mirasbırakanın tenkise tabi sağlararası tasarrufları sıralanmıştır. Bu sayılanlar dışında, miras bırakan sağlığında kendi

can, Ömer Uğur (2011) Miras Hukuku, 2. Baskı, Ankara, Yetkin Yayınları, s. 536; İnal, Nihat (2016) Miras Davaları, 5. Baskı, Ankara, Bilge, s. 355; Kazancı, İdil Tuncer /Apaydın, Bahar Öcal (2015) "Mirasçıların Alacaklılarını Koruyan Davalar İle Tasarrufun İptali Davası İlişkisi", İnönü Üniversitesi Hukuk Fakültesi Dergisi Özel Sayı C: 2, s. 778; Turanboy, Nuri (2010) Mirasbırakanın Denkleştirme ve Tenkise Bağlı Sağlar Arası Hukuki İşlemleri, Ankara, s.32; Kaçak, Nazif (2006) Miras Hukuku, 1. Baskı, Ankara, Seçkin, s. 156; Serozan / Engin, s. 243; Kocayusufpaşaoğlu, s. 412.

5 Öztan, s. 113; Antalya, s. 291; Yavuz, Cevdet (1985) "Miras Hukukunda Tenkisten Sonra Tenkis Konusu Geri Verme (İade) Yükümlülüğü", İstanbul Üniversitesi Hukuk Fakültesi Dergisi, C: LI. S: 1, s. 278.

6 İmre / Erman, s. 261; İnan / Ertaş / Albaş, s. 388; Başara, s. 369 (Tenkis); Uyar, s. 406; Tüfek, s. 101.

7 Özdoğan, s. 364; Oral, Alkım (2018) " Miras Hukukunda Tenkis Davası", (Yüksek Lisans), Akdeniz Üniversitesi, Sosyal Bilimler Enstitüsü s. 27; Tüfek, s. 101.

Oral, s. 30; Gençcan, s. 446.

$9 \quad$ Eren, Fikret (1973) Türk Medeni Hukukunda Tenkis Davası, Ankara, Ankara Üniversitesi Hukuk Fakültesi Yayınları, s. 8; Yazar, İbrahim (2017) "Miras Hukukunda Tenkis", Kadir Has Üniversitesi, Sosyal Bilimler Enstitüsü, s. 6. 
malvarlığ 1 değerleri üzerinde dilediği gibi tasarrufta bulunabilir. ${ }^{10}$ Ancak bu sağlararası tasarruflar, TMK'nın m.565 kapsamındaki tasarruflardan ise, bu durumda ölüme bağlı tasarruflar gibi tenkise tabi olacaklardır. TMK'nın m. 565 hükmüne göre ; " Aşağıdaki karşıllksız kazandırmalar, ölüme bağh tasarruflar gibi tenkise tâbidir:

1. Mirasbırakanın, mirasçılık sıfatını kaybeden yasal mirasçıya miras payına mahsuben yapmış olduğu sağlararası kazandırmalar,geri verilmemek kaydıyla altsoyuna malvarlğ̆ devri veya borçtan kurtarma yoluyla yaptı̆̆ kazandırmalar ya da alışılmışın dışında verilen çeyiz ve kuruluş sermayesi,

2. Miras haklarının ölümden önce tasfiyesi maksadıla yapılan kazandırmalar,

3. Mirasbırakanın serbestçe dönme hakkını saklı tutarak yaptığı bağışlamalar ve ölümünden önceki bir yıl içinde âdet üzere verilen hediyeler dışında yapmış olduğu bağışlamalar,

4. Mirasbırakanın saklı pay kuralların etkisiz kılmak amacıyla yaptı̆̆ı açık olan kazandirmalar."

Çalışmamızda, tenkis davasıyla sıkça karıştırılan denkleştirme davası, miras sebebiyle istihkak davası ve ölüme bağlı tasarrufun iptali davası arasındaki farklılıkları, öğretideki görüşler ve Yüksek Yargı kararları ile ayrıntılı biçimde incelenecektir.

\section{MİRASTA DENKLEŞTİRME İLE KARŞILAŞTIRMA}

\section{A. GENEL OLARAK DENKLEŞTIRME}

Tenkis ile karıştırılması en müsait kurum olduğu söylenebilecek denkleștirme, tıpkı tenkis gibi Türk Miras Hukuku'nun miras paylarının belirlenmesi hükümlerini içerir. ${ }^{11}$ TMK m. 669-675 arasında düzenlenen mirasta denkleştirme, mirasbırakanın mirasçılara yaptığı sağlararası karşılıksız kazandırmalar sebebiyle, mirasçılar arasında eşitliği sağlayan bir kurumdur. Denkleştirmede mirasçı, eşitliğin sağlanması amacıyla aldığı değerleri terekeye iade etmektedir. ${ }^{12}$ Mirasbırakan sağlığında, belli şartlara uymak koşuluyla istediği gibi tasarrufta bulunabilir. Fakat yasal mirasçılarına yaptığı karşılıksız

\footnotetext{
Hatemi, s. 56.

Güleş, Bedia (2018) "Türk Miras Hukukunda Denkleștirme", Türkiye Barolar Birliği Dergisi, S: 134, s. 370. Göktürk, s. 154; Uyar, s. 408; Nar, s. 34; Öztürkler, s. 95; Hatemi, s. 54; Kılıçoğlu, s. 469; Antalya, s. 451; Başara, Gamze Turan (2013) Miras Hukukunda Denkleştirme, Ankara, Turhan Yayınevi, s. 5. (Miras); İnal, s. 978; Aydın Ünver, Tülay (2011) "Miras Bırakanın Yasa Gereği Denkleștirmeye Tabi Olan Kazandırmaları", Prof. Dr. Şener Akyol'a Armağan, İstanbul, Filiz Kitabevi, s. 114; Karayalçın, Yaşar (2000) Mirasbırakanın Muvazaası Mı? Tasarruf Özgürlüğü ve Saklı Payın Korunması Mı? Bir Tartışma, Ankara, Turhan Kitabevi, s. 85; Ozanemre Yayla, Hatice Tolunay (2011) Mirasın Paylaşılması, Ankara, Turhan Kitabevi, s. 157.
} 
kazandırmaları malvarlı̆̆ından ayırıp, onlara vermişse, bu işlem dolayısıyla mirasbırakanın terekesindeki mallarda azalma olabileceği gibi, öbür yasal mirasçıların miras haklarında azalma gerçekleşebilir. Bu halde diğer mirasçılar, koşulları oluşursa, mirasta denkleştirme yoluna başvurabilirler. Mirasta denkleştirmenin amacı, yasal mirasçıllğı korumak ve altsoylar arasındaki eşitliği, adaleti ve hakkaniyeti sağlamaktır. ${ }^{13}$ Yargitay, murisin oğluna verdiği vekaletname ile kendisine ait banka hesaplarından para çekme yetkisi verdiği, davalının para çekme yetkisini murisin ölüm tarihine yakın süre içinde kötüye kullanarak bankada bulanan tüm paraları uhdesine aldığı, murisin paraların çekiminden kısa süre sonra vefat ettiği bir olayda, çekilen paranın murisin son anlarında kendisine harcandığına ilişkin delil sunamadığı, paranın murise harcanmadığ kendisine olacak şekilde çekildiğini kabul ederek, davacıların hissesine düşen miktar yönünden murisin ölüm tarihinden itibaren işleyecek yasal faizi ile birlikte denkleştirme kararı veren mahalli mahkeme kararını onamıştır. ${ }^{14}$

Mirasta denkleştirmenin koşulları, kazandırmanın sağlararası ve karşılıksız olması, mirasbırakanın malvarlığından çıkmış olması ve yasal mirasçının miras payına mahsuben yapılmış olmasıdır. ${ }^{15}$ Tenkis davası ve denkleştirme davası, birbirinden bağımsız ve farklı iki kurumdur. Miras hukukunda tenkis talebiyle, mirasçıların saklı paylarını elde etmeleri amaçlanırken, denkleştirmeyle yasal mirasçlar arasında eşitliğin sağlanması amaçlanır. Bu iki talebin birlikte ileri sürülmesi kural olarak mümkün değildir. ${ }^{16}$ Ancak istisnai nitelikteki TMK'nın m. 565/b.1 hükmüne göre, "kanuni veya iradi denkleştirmeye tabi olan bir kazandirma ancak denkleştirme yükümlülü̈̆̈̈nden kurtulduktan sonra tenkise tabi olur". Bu nedenle, saklı paylı mirasçının denkleştirme talebini ileri sürülebildiği hallerde tenkis talebinde de bulunmasında hukuki yarar bulunmamaktadır. Zira denkleştirme yoluna başvuran mirasçı, saklı payı da kapsayan yasal miras hakkını elde eder. Çoğun içinde azda bulunur ilkesi gereğince, denkleştirme sonucunda kazandırmanın tamamı terekeye iade edileceğinden tenkis talebinde bulunması gereksizdir. Ancak bazı durumlarda bir mirasçı denkleştirme talebinde bulunsa bile saklı payını elde edemeyebilir. Bu durumda tenkis talebinden başka çare yoktur. ${ }^{17}$ Ancak, denkleştirme talebinin, kendiliğinden tenkis davasına dönüşmesi mümkün değildir. ${ }^{18}$ Yargıtay, böyle bir durumda davanın ıslahını ya da terditli dava açılması

13 Kocayusufpaşaoğlu, s. 438; Oral, s. 75; Güleş, s. 361; Nar, s. 34; Özuğur, s. 474; Antalya, s. 450; Başara, s. 6 ( Miras ); Turanboy, s. 31.

14 Yargitay 14. Hukuk Dairesi, E: 2016/11377, K: 2019/4702, T: 23.05.2019 (UYAP).

15 Kocayusufpaşaoğlu, 441; Antalya, s. 455; Yazar, s. 47; Ayan, s. 311; Kılıçoğlu, s. 470; Özuğur, s. 475; İnan / Ertaş / Albaş, s. 590; Dural / Öz, s. 330; Başara, s. 45 (Miras); Aydın Ünver, s. 132.

Başara, s. 32 (Miras).

Güleș, s. 373.

Turanboy, s. 32. 
gerektiğine isabetle işaret etmiştir. ${ }^{19}$

Öğretide, denkleştirme talebi sonucu miras payını elde edemeyen mirasçının tenkis talebini ileri sürülebileceği iki istisna kabul edilmektedir. İstisnalardan birincisi, TMK'nın m. 672 hükmünde belirtilen düzenlemedir. Bu hükme göre; "... yapılan kazandırma miras payını aştı̆̆ı takdirde mirasçı, mirasbırakanın bunu kendisine birakmak istediğini ispat ederse, bu fazlalk denkleştirmeye tabi olmaz. Diğer mirasçıların tenkise ilişkin hakları saklıdır." Böylelikle, denkleştirmeye konu kazandırma, mirasçıların yasal miras paylarını aşsa bile, aşan kısım ile birlikte denkleştirmeye tabi olur. Bunun yanında, mirasçı, payını aşan kısmı, mirasbırakanın kendisine bırakmak istediğini kanıtlarsa, fazlalık kısım denkleştirmeye tabi tutulmayacaktır. $\mathrm{Bu}$ durumda, saklı payının karşlığını alamayan mirasçılar, şartların bulunması halinde aşan kısmın tenkisini isteyebileceklerdir. ${ }^{20}$ Öğretide, denkleştirme talebinden sonra ileri sürülebilecek tenkis talebinin istisnai diğer halini, sağ kalan eşin altsoyla birlikte mirasçı olmasıdır. TMK md. 669/2'ye göre, doğacak yasal denkleştirme yükümlülüğünün ifası sadece altsoy tarafından talep edilebilir. ${ }^{21} \mathrm{Bu}$ nedenle altsoyla birlikte mirasçı olan sağ kalan eşin, altsoya karşı denkleştirme talebinde bulunması mümkün değildir. Bununla birlikte, TMK m. 669/2 kapsamında denkleştirme alacaklısı olamayan sağ kalan eş, saklı paylı mirasçı sıfatına sahip olduğu için söz konusu kazandırma için tenkis talebinde bulunabilecektir. ${ }^{22}$ Yargitay, terditli olarak denkleştirme ve tenkis taleplerinin ileri sürülmüş olduğu bir davada, öncelikle denkleştirmenin, bunun mümkün olmaması halinde tenkise başvurulması gerektiğine isabetle karar vermiştir. $^{23}$

19 ".... Mirasta denkleştirme davalarında, sadece yasal mirasçı aleyhine denkleştirme talebinde bulunulabilir, yasal mirasçı olmayanlara yapılan kazandırma denkleştirmeye tabi değildir. Miras bırakandan sağlar arası kazandırma olmalıdır. Ölüme bağlı tasarrufla yapılan kazandırma denkleștirmeye tabi değildir. Kazandırma karşıllksız olmalıdır. Kazandırma, miras payına mahsuben (iadeye tabi olarak) yapılmalıdır. Bağış amaçlı yapılan kazandırmalar denkleştirmeye (iadeye) tabi yapılan kazandırma aksi miras bırakan tarafindan açıkça belirtilmemişse karine olarak denkleştirmeye (iadeye) tabidir. Altsoya yapılan sağlar arası kazandırmanın denkleştirmeye tabi olmadiğını davalı (altsoy) ispatlamalıdır. Altsoy dışındaki yasal mirasçılara yapılan kazandırma, karine olarak denkleştirmeye (iadeye) tabi değildir. Altsoy dışındaki yasal mirasçıya yapılan kazandirmanin Denkleștirmeye (iadeye) tabi olduğunu davact ispatlamalıdır. Miras burakanın iradesinin denkleştirmeye (iadeye) tabi olup olmadığının ispatı şekle tabi değildir, her türlü delille ispatlanabilir. İade edilecek mal varlı̆̆ yönünden seçim hakk davalinındır; ister aynen iade eder, isterse bedelini öder. Miras payının aşan kasminin davalıda kalması miras birakanin iradesinden anlaşlliyorsa, aşan ksım için iade istenemez. Denkleştirme, denkleștirme anındaki değere göre yapllr. Denkleştirmede sebepsiz zenginleşme hükümleri uygulanır. Islah olmadıkça ya da terditli dava açılmamuşsa kendiliğinden tenkis davasına dönü̧smez. "Yarg1tay 14. Hukuk Dairesi, E: 2016/9041, K: 2019/3588, T: 18.04.2019 (UYAP).

20 İmre / Erman, s. 515.

21 Antalya, s. 453; Başara, s. 44 (Miras).

22 İmre / Erman, s. 516; Nar, s. 34; Ayan, s. 309; İnan / Ertaş / Albaş, s. 594; Başara, s. 45 (Miras).

23 "Somut olaya gelince; davacılar dava dilekçelerinde, mirasbırakan tarafindan davaliya yapılan bağıs işleminin mirasçılardan mal kaçırmak amacıyla ve davalının miras payına mahsuben yapıldı̆̆ı̆n ileri sürerek öncelikle denkleștirme nedeniyle taşınmazın tapusunun iptali ile terekeye iadesi olmazsa tenkisine karar ve- 


\section{B. TENKISS DAVASI İLE DENKLEȘTİRME ARASINDAKİ}

\section{FARKLILIKLAR}

\section{Konu ve Amaç Bakımından}

Mirasbırakanın ölüme bağlı tasarrufları ve sağlararası karşılıksız kazandırmaları tenkis davasının konusunu oluşturur. Denkleştirmenin konusu ise, sadece mirasbırakanın sağlararası karşılıksız kazandırmalarıdır. ${ }^{24}$ Ölüme bağlı tasarrufların denkleştirmeye konu olması söz konusu değildir. Bu nedenle tenkise tabi kazandırmaların konusu, denkleştirmeye tabi olan kazandırmalardan daha geniştir. ${ }^{25}$ Tenkise ilişkin kurallar, emredici nitelikte oldukları için mirasbırakanın iradesiyle değiştirilemezler. ${ }^{26}$ Mirasbırakanın iradesiyle, tenkise konu bir kazandırmayı tenkise tabi olmaktan çıarması hükümsüzdür. Denkleştirmeye ilişkin kurallar ise, tamamlayıcı niteliktedir. TMK'nın m. 669 hükmüne göre, mirasbırakan bu kuralların uygulanıp uygulanmayacağına kendi iradesiyle karar verebilir. Bu nedenle mirasbırakan, kanunen yükümlü olmayan bir mirasçısını denkleştirme ile yükümlü kılabilirken, denkleştirme yükümlüsü bir mirasçısını da bu yükümlülükten kurtarabilir. ${ }^{27}$

Tenkis davasının amacı, mirasbırakanın tasarruf özgürlüğü sınırlarını aşmak suretiyle, saklı pay oranlarını ihlal eden tasarruflarının, yasal sınıra indirilmesidir. ${ }^{28}$ Mirasta denkleştirmesinde ise, yasal mirasçılar lehine yapılmış olan sağlararası karşılıksız kazandırmaların terekeye iadesi veya miras payına mahsup edilmesiyle, yasal mirasçıların miras paylarını almalarını sağlar. Mirasçılar arasında eşitliği sağlanmayı amaçlayan denkleştirme, yasal mirasçılığı tamamlayıcı niteliktedir. ${ }^{29}$

Tenkis davası, yenilik doğuran bir davadır. Denkleştirme davasının niteliği ise talep içeriğine göre belirlenir. Buna göre yalnızca denkleştirme alacağının varlığının tespitine yönelik bir dava varsa tespit davası, buna karşılık denkleştirme konusunu paylaştırma prosedürü içinde elde etmeye yönelik bir dava varsa ifa davası söz konusudur. $^{30}$

rilmesi istemiyle terditli dava açmışlar ancak, mahkemece denkleştirme nedeniyle açılan dava hakkında olumlu veya olumsuz bir karar verilmeksizin, terditli isteklerden tenkis istemi yönünden hüküm kurulmuştur. Hal böyle olunca, toplanılan tüm deliller değerlendirilmek suretiyle öncelikle iptal-tescil isteği bakımından bir karar verilmesi gerekirken HMK'nun 297/2. maddesine aykirl biçimde terditli isteklerden denkleştirme nedeniyle tapu iptal ve tescil istemi yönünden olumlu veya olumsuz bir karar verilmeksizin tenkis istemi yönünden hüküm kurularak yazılı şekilde neticeye gidilmiş olması doğru değildir." Yargıtay 1. Hukuk Dairesi, E: 2014/15467, K: 2016/3677,T: 28.3.2016 (UYAP).

24 Güleş, s. 372; Dural / Öz, s. 320; Başara, s. 30 (Miras); Tüfek, s. 105.

25 Nar, s. 39.

26 Dural / Öz, s. 290; Nar, s. 39; İmre / Erman, s. 515; Başara, s. 33 (Miras); Ozanemre Yayla, s. 73.

27 İmre / Erman, s. 516; Antalya, s. 453; Kocayusufpaşaoğlu, s. 438; Başara, s. 33 (Miras).

28 Ayan, s. 219; Kılıçoğlu, s. 247; Dural / Öz, s. 320; İmre / Erman, s. 262; Gönensay / Birsen, s. 74.

29 Nar, s. 42; Güleş, s. 371; İmre / Erman, s. 516; Gençcan, s. 534.

30 Güleș, s. 372. 


\section{Taraflar}

Denkleştirme talebinde bulunacak kişinin mirasçı olması gerekli ise de, saklı paylı mirasçı olması gerekmez. Mirasçıların alacaklıları veya iflas idaresi, mirasçı olmadıkları için denkleştirme talebinde bulunamazlar. TMK md.669/1'e göre, bir mirasçının denkleştirme talebinde bulunabilmesi için, birden fazla mirasçının olması gerektiği anlaşılır. Tenkis talebinde bulunabilecekler, saklı paylı mirasçılar ve bazı durumlarda mirasçıların alacaklıları veya iflas idaresidir. ${ }^{31}$ Saklı paylı mirasçıların dışındaki mirasç̧lar, tenkis talebinde bulunamaz. Bu nedenle tenkis davasında davacılar, denkleştirme talebinde bulunabilecek kişilerden daha dardır. ${ }^{32}$ Denkleştirme talebinde birden fazla mirasçı bulunması gerekmekte iken, tenkis talebinde bulunabilmek için sadece bir saklı paylı mirasçının bulunması yeterlidir. TMK m. 669/1 hükmüne göre, " Yasal mirasçılar, mirasbırakandan miras paylarına mahsuben elde ettikleri sağlararası karşılıksız kazandırmaları, denkleştirmeyi sağlamak için terekeye geri vermekle birbirlerine karşı yükümlüdürler." Hükmün yorumundan ve mantık kuralları gereğince, mirasbırakanın yasal mirasçısının bir kişiden ibaret olduğu durumlarda, denkleștirmeden söz etmek mümkün değildir. ${ }^{33}$

Tenkis davasında davalılar, saklı payları ihlal eden kazandırmaların lehine yapıldığı kişilerdir. Bu kişiler, diğer mirasçılar ya da sair üçüncü kişiler olabilir. ${ }^{34}$ Buna karşılık, denkleştirmede ise davalı yanda her zaman yasal mirasçılar bulunur. Çünkü denkleştirme, yasal mirasçılığı tamamlayan ve mirasçılar arasında eşitliği sağlama amacı güden bir kurumdur. ${ }^{35}$ Feragat, çıkarma, yoksunluk gibi sebeplerle mirasçllık sıfatını kaybeden mirasçllar ve üçüncü kişiler denkleştirme yükümlüsü olamaz. ${ }^{36}$ Zira TMK m. 670 hükmüne göre, " Mirasın açılmasından önce veya sonra mirasçllı sıfatım kaybeden mirasçıya ait geri verme yükümlülüğ̈̈, onun yerini alan mirasçılara, miras paylarında meydana gelen artış oranında geçer." Ancak bu kişiler lehine yapılan kazandırmalar denkleştirmeye konu olamamakla birlikte, saklı payları ihlal ettikleri takdirde tenkise tabi olabilirler. ${ }^{37}$

\section{Süre}

TMK m. 571/1 hükmüne göre, "Tenkis davası açma hakkı, mirasçıların

31 Güleș, s. 372; Serozan / Engin, s. 245; Kılıçoğlu, s. 253; İnan / Ertaş / Albaş, s. 390; Öztan, s. 115; Antalya, s. 292; Kazancı /Apaydın, s. 779.

Nar, s. 40; Kocayusufpaşaoğlu, s. 443.

Dural / Öz, s. 321; İmre / Erman, s. 516; Nar, s. 41.

34 Ayan, s. 221; Kılıçoğlu, s. 255; İnan / Ertaş / Albaş, s. 394; Dural / Öz, s. 326; Tüfek, s. 105; Kazancı, /Apaydın, s. 784.

35 Nar, s. 41; Serozan / Engin, s. 247; İnan / Ertaş / Albaş, s. 590; Dural / Öz, s. 321; İmre / Erman, s. 517; Antalya, s. 452; Başara, s. 35 (Miras).

36 Antalya, s. 455.

37 Nar, s. 41; İmre / Erman, s. 516; İnan / Ertaş / Albaş, s. 590. 
saklı paylarının zedelendiğini öğrendikleri tarihten başlayarak bir yıl ve her halde vasiyetnamelerde açılma tarihinin, diğer tasarruflarda mirasın açılması tarihinin üzerinden on yıl geçmekle düşer.” Maddeden de anlaşıldığı üzere, tenkis davasının açılması bakımından bir ve on yıllık iki farklı hak düşürücü süre düzenlenmiştir. ${ }^{38}$ Dava açma hakkına sahip olan kişilerin, tenkis taleplerini bu süreler içinde ileri sürmeleri gerekir. Bunun yanında TMK md. 571/3'e göre, saklı paylı mirasçlara karşı henüz yerine getirilmemiş tasarrufların ifası talebi varsa, saklı paylı mirasçılar tenkis defini ileri sürebilirler. ${ }^{39}$ Denkleştirmenin ne zamana kadar talep edilebileceğine ilişkin Kanun'da bir düzenleme bulunmamakla birlikte, denkleştirme talebi mirasın paylaşılması aşamasında ortaya çıktığı için, öğretide denkleştirme davasının da miras paylaşılmasının tamamlanmasına kadar açılması mümkün sayılmaktadır. ${ }^{40}$ Mirasın paylaşılmasının gerek mirasçıların anlaşmasıyla, gerekse hakim kararı ile gerçekleşmesinden sonra denkleştirme talebini ileri sürme hakkı sona erer. ${ }^{41}$ Yargıtay verdiği bir kararda, dava tarihi itibariyle murisin terekesinin henüz paylaşılmadığı için zamanaşımı süresinin dolmadığını belirtmiştir. ${ }^{42}$

\section{MİRAS SEBEBİYLE İSTİHKAK DAVASI İLE KARŞILAŞTIRMA A. GENEL OLARAK MİRAS SEBEBİYLE İSTİHKAK DAVASI}

Bir hakkın sahibi, onu haksız yere elinden tutandan geri vermesini isteyebilir. ${ }^{43}$ Mirasbırakanın ölümü üzerine mirasçılar, külli halefiyet ilkesi uyarınca, mirasa kendiliğinden ve bir bütün olarak sahip olduklarından, onların tereke üzerindeki kendilerine intikal etmiş bu haklara dayanarak, terekeye kısmen veya tamamen el koymak isteyen kişilerden bunları talep edebilirler. ${ }^{44}$ Mirasçılara zilyedliği koruyucu dava ve idari yollara müracaat haklarının yanı sıra, ayrıca

38 Güleș, s. 373; Serozan / Engin, s. 251; Ayan, s. 224; Kılıçoğlu, s. 257; Sarı, s. 97; İnan / Ertaş / Albaş, s.399; Dural / Öz, s. 285; Öztan, s. 120; Antalya, s. 305; Kaçak, s. 212; Başara, s. 38 (Miras).

39 Nar, s. 42; Serozan / Engin, s. 251; Kılıçoğlu, s. 257; İnan / Ertaş / Albaş, s. 397; Antalya, s. 306; Karayalçın, s. 85; Kaçak, s. 212.

40 Nar, s. 43; İnan / Ertaş / Albaş, s. 595; Dural / Öz, s. 321; Başara, s. 219 (Miras).

$41 \quad$ Nar, s. 43.

42 “... Mirasta denkleştirme istemi mirasın paylaşılması tamamlanana kadar gerçekleştirilebilir. Başka bir anlatımla mirasta denkleştirme istemi miras paylaşılmadı̆̆ sürece zamanaşımına uğramaz. Mirasın taksimi halinde ise taksimin yapılmasından itibaren on yllık zamanaşımı süresi içinde mirasta denkleştirmenin istenmesi gerekir. Yukarıdaki açıklamalar ışığında dava konusu olaya bakıldığında... dava tarihi itibariyle murisin terekesinin henüz paylaşılmadığına göre zamanaşımı süresinin dolmadığı anlaşılmaktadır. O halde, ... mirasın taksimi talep edilmedikçe denkleştirmenin yapılmayacağ gerekçesiyle davanın reddi isabetsiz olmuş ve bozmay gerektirmiştir.” Yargitay 2. Hukuk Dairesi, E: 2013/25017, K: 2014/573, T: 16/01/2014.

43 Öztürkler, s. 107.

44 Nar, s. 43; Ayan, s. 314; Hatemi, s. 171; Özuğur, s. 1475; İnan / Ertaş / Albaş, s. 539; Gençcan, s. 1210; İnal, s. 853; Akbıyık, Cem (2003) Miras Sebebiyle İstihkak Davası, İstanbul, Der Yayıncılık, s. 318; Tandoğan, s. 271; Kaçak, s. 364. 
TMK sadece mirasçılık sıfatlarından dolayı, miras haklarını koruyan özel bir dava hakkı tanımıştır. TMK'nın 637-639. maddelerinde düzenlenen bu dava, miras sebebiyle istihkak davasıdır. ${ }^{45}$ TMK m. 637/1 hükmüne göre, " Yasal veya atanmış mirasçı, terekeyi veya bazı tereke mallarını elinde bulunduran kimseye karşı mirasçılıktaki üstün hakkını ileri sürerek miras sebebiyle istihkak davası açabilir."

Miras sebebiyle istihkak davası, terekede yer alan bir malı veya hakkı iade etmesi gereken herkese karşı yöneltilebilir. Adi istihkak davasından farklı olarak, miras sebebiyle istihkak davasına taşınır ve taşınmaz eşyalar dışındaki tereke unsurları (fikri haklar, alacak hakları) da girebilir. TMK'nın m. 637 / 1 hükmüne göre, miras sebebiyle istihkak davası sadece belirli tereke mallarına haksız zilyet olanlara karşı da açılabilen bir eda davasıdır. ${ }^{46}$

TMK'nın m. 637-639 hükümleri arasında düzenlenen miras sebebiyle istihkak davası, mirasbırakandan külli halefiyet yoluyla mirasçıya geçen aynı ve şahsi iade davalarından oldukça farklıdır. Adi istihkak, menkul, akdi ifa ve iade, sebepsiz zenginleşme gibi davalar yoluyla mirasçı, mirasbırakanın sağlı̆̆ında verdiği malları külli halefiyet yoluyla kendisine geçen akti ya da ayni iade davalarıyla talep edebilir. Ancak mirasçı, mirasbırakanın ölümünden sonra el konmuş olan terekedeki parayı ve eşyayı kendi mirasçılık sıfatına dayanan miras sebebiyle istihkak davası ile geri ister. ${ }^{47}$ Miras sebebiyle istihkak davası, zilyet olmayan mirasçının, mirasçı olmayan haksız zilyete karşı açtığı davadır. Mirasçılık sıfatını taşımaları sebebiyle aslen ve doğrudan doğruya mirasçıların şahıslarından doğan bu dava, mirasçılara mirasbırakandan intikal eden bir dava değildir. ${ }^{48}$

\section{B. TENKİS DAVASI İLE MİRAS SEBEBIYYLE İSTİHKAK DAVASI ARASINDAKI FARKLILIKLAR}

\section{Konu ve Amaç}

Tenkis davasıyla, saklı payları ihlal eden kazandırmaların yasal sınıra çekilmesini amaçlanır. Miras sebebiyle istihkak davasının amacı ise, yasal ve atanmış mirasçıların tereke üzerindeki haklarını korumaktadır. Tenkise konu olan kazandırma, saklı payları ihlal ettiği ölçüde hükümsüzdür. Kazandırmanın bir kısmı saklı payı ihlal ediyorsa, sadece o kısmı geçersiz olur. Tenkis davası sonucunda alınan yenilik doğuran kararla, lehdar saklı paylı mirasçıya bir şey

45 Petek, Hasan ( 2012 ) " Miras Sebebiyle İstihkak Davası ile Adi İstihkak Davası Yarışır mı?", Yaşar Üniversitesi Hukuk Fakültesi Dergisi, S: 1, s. 28; Nar, s. 43; Öztan, s. 426.

46 Petek, s.20; Öztürkler, s. 108; Gençcan, s. 1217; Eren, s. 105 (İstihkak ); Tandoğan, s. 274

47 Serozan / Engin, s. 549; İnan / Ertaș / Albaș, s. 539.

48 Eren, s. 1047 (İstihkak). 
vermeye zorlanamaz. Böylelikle saklı payı ihlal eden kazandırmanın, yasal sınırlara çeken tenkis davasından sonra davacının ayrıca eda davası açması gerekir. ${ }^{49}$ Ancak Yargıtay, tenkis davasını iki aşamaya ayırarak saklı payın ihlalinin saptanmasını tespit davası, bilahare saklı payın ne miktar tecavüze uğradığı ve bu kısmın mirasçıya iadesi hususu talebini de davanın eda kısmı olduğuna hükmetmiştir. ${ }^{50}$

Miras sebebiyle istihkak davası, dava konusu edilen şey zilyedinden alınarak tamamen geri verilmesini konu edinen bir eda davasıdır. $\mathrm{Bu}$ dava ile davalı, davacıya karşı bir edimde bulunma ( tereke konusu hak ve malları verme ) borcu altına girmektedir. ${ }^{51}$ Yargitay, mirasta iade, olmazsa tenkis isteğine ilişkin olarak açılan terditli bir davada, davalının mirasçı olmaması sebebiyle denkleştirme hükümlerinin uygulanamayacağına işaret ettikten sonra, miras sebebiyle istihkak davasının koşullarının aranmasını, mümkün olmadığı takdirde tenkis yönünden inceleme yapılmasını belirtmiştir. ${ }^{52}$

\section{Taraflar}

Tenkis davasını, saklı pay sahibi mirasçılar ve bazı durumlarda saklı pay sahibi mirasçıların alacaklıları veya iflas idaresi açabilir. Miras sebebiyle istihkak davasını ise, tereke üzerinde sahip olduğu ayni hakkı ihlal edilen yasal veya atanmış mirasçılar açabilir. Miras sebebiyle istihkak davasının davacıları, saklı pay sahibi olup olmamalarının bir önemi bulunmadığından, tenkis davasının davacılarına göre fazladır. ${ }^{53}$ Terekeyle doğrudan ilişkisi olmayan mirasçıların alacaklıları ya da iflas idaresi, terekeye ilişkin olan miras sebebiyle istihkak

49 Nar, s. 47; İnan / Ertaş / Albaş, s. 388; Dural / Öz, s. 277; Antalya, s. 292; Başara, s. 31 ( Miras ); Eren, s. 1052 ( İstihkak ); Uyar, s. 407; Yavuz, s. 291.

$50 \quad$ "...Diğer taraftan, doktrinde sakl paylarının değerini alamayan mirasçların miras burakanlarının, mirastan tasarruf edebileceği kismı aşan yani sakl paylarına yaptığ tecavüzü ortadan kaldırmak ve geri alınmasını sağlamak için açttkları davalar ise tenkis(İndirim) davaları olarak adlandırılmaktadır(4721 Sayll TMK madde 569). Miras birakanın, saklı paya tecavüzünün bulunup bulunmadığını tespiti davanın tespit kismıdır. Bu işlem tespit edildikten sonra da ne miktar payın tecavüze uğradığı ve bu kismın mirasçıya iadesi hususu da davanin eda kismıdır. Tenkis davasında; miras bırakanın, mirasçını sakl payına tecavüz ederek vasiyetle veya ölüme bağll diğer bir tasarrufla başka bir mirasçıya veya üçüncü kişiye bağışta bulunmuş olmasl, davanın açılması koşuludur. Miras Hukukundaki tenkis davaları, özünde geçerli olan işlemler için açılabilir." Yargitay Hukuk Genel Kurulu, E: 2011/2-515,K: 2011/605, T:12.10.2011 ( UYAP ).

51 Dural / Öz, s. 445; Nar, s. 47; Öztan, s. 426; Eren, s. 1048 (İstihkak ); Tandoğan, s. 272.

52 “Bilindiği üzere; TMK'nin 669. maddesinde 'yasal mirasçlar, mirasbirakandan miras paylarına mahsuben elde ettikleri sağlar arası karşıllksız kazandırmaları, denkleştirmeyi sağlamak için terekeye geri vermekle birbirlerine karşı yükümlüdürler hükmüne yer verilmiştir. Somut olayda davalı mirasçı değildir. Dolayısıyla 669. maddenin uygulama yeri yoktur. Hemen belirtilmelidir ki, TMK 637 ve devamı maddelerinde miras sebebiyle istihkak davası düzenlenmiştir. Ne var ki; mahkemece bu yönde bir inceleme yapılmadığ gibi tenkis yönünden de bir inceleme yapllmamuştrr. Hal böyle olunca; öncelikle iddianin miras sebebiyle istihkak baklmindan incelenmesi bunun koşullartnın oluşmadığı saptanır ise tenkis yönünden inceleme yapılması gerekirken değinilen hususları içermeyen biçimde yazıll şekilde karar verilmesi doğru değildir." Yargitay 1. Hukuk Dairesi, E: 2016/1070, K: 2018/15646, T: 17.12.2018 (UYAP).

53 Nar, s. 48; Serozan / Engin, s. 553; Oral, s. 81. 
davasını açamazlar. ${ }^{54}$

Yargıtay, mirasbırakanın hiçbir mirasçısının tespit edilemediği bir olayda, TMK.nun 594. maddesinde belirtilen ilanların yapılmadan ve mahallinde keşif yapılarak mahalli bilirkişilerin dinlenilmeden miras sebebiyle istihkak davası açma hakkı saklı kalmak üzere, mirasın devlete geçeceğine dair verilen kararı isabetli olarak bozmuştur. ${ }^{55}$

Tenkis davasında davalı, kendi lehine tenkise konu bir kazandırma yapılan kişidir. Davalı, mirasçılardan biri olabileceği gibi, üçüncü bir şahıs da olabilir. Bu kişilere karşı tenkis talebinin ileri sürülebilmesi için, kazandırmayı elinde bulunduranların zilyetliklerin haksız olması koşulu gerekmez. ${ }^{56}$ Davalının, kazandırmayı haksız olarak elinde bulundurması halinde, zilyetliği koruyan başka bir davanın açılması ya da idari mercie başvurulması gerekecektir. Miras sebebiyle istihkak davasının davalısı, tereke mallarını mirasçılık iddiasıyla ya da böyle bir iddiası olmaksızın haksız olarak elinde bulunduran üçüncü kişilerdir. ${ }^{57}$ Terekede bulunan mallar üzerindeki zilyetliği hakka dayanan zilyetlere karşı bu davanın açılması mümkün değildir. Bu nedenle, bir kişiye karşı aynı anda hem tenkis davası hem de miras sebebiyle istihkak davası açılamaz. ${ }^{58}$ Yargıtay, davacı tarafından açlan muris muvazaası hukuksal nedenine dayalı tapu iptali ve tescil, olmazsa tenkis, aksi halde miras sebebiyle istihkak davasında öncelikle tenkis

54 Dural / Öz, s. 447; Nar, s. 47; Serozan / Engin, s. 552; Ayan, s. 314, Özuğur, s. 1478; İnan / Ertaş / Albaş, s. 448; Öztan, s. 429; Akbıylk, s. 155; Eren, s. 1054 (İstihkak); Tandoğan, s. 274.

55 " 4721 sayll TMK.nun 594. maddesi hükmünde, mirasbirakanin mirasçısı bulunup bulunmadı̆̆ veya mirasçların tamamı bilinmiyorsa, sulh hâkiminin uygun araçlarla ve bir ay ara ile iki defa ilân yapıp hak sahiplerini son ilândan başlayarak en geç bir yll içinde mirasçılı sıfatlarını bildirmeye çağıracağı, ilân süresinde kimse başvurmazsa ve sulh hâkimi de hiçbir mirasçı tespit edememişse, miras sebebiyle istihkak davası açma hakkı saklı kalmak üzere mirasın devlete geçeceği belirtilmiştir.

Davada sağllkl bir sonuca varllabilmesi için miras birakanın ve mirasçllartnin nüfus kayttlar ile adreslerinin belirlenmesi, bu bilgilerin elde edilebilmesi için bütün imkanlarn kullanılması gerektiği kuşkusuzdur. Ne var ki, mahkemece tapu kaytlart ve dayanak belgeleri getirtilerek, miras birakanin nüfus kayıt bilgileri ve adresi araştrılmamış, bu hususlar tapu sicil müdürlüğ̈̈nden sorulmamıs ve mirasçı bırakmaksızın ölen kişsinin son mirasçısınin Hazine olacağ ve TMK.n 594. maddesindeki ilanlarn yapllmast gerektiği düşünülmeksizin yasal düzenlemeler göz ardı edilerek eksik araştırma ve soruşturma ile davanin reddine karar verilmişstir.

Dosyada bulunan 20.12.1952 tarihli kadastro tutanaklarında Mustafa oğlu Ahmet'in mirasçılarından söz edilmektedir. Mahkemece 20.12.1952 tarihli kadastro kaytlarının dayanağını teşkil eden 26.09.1941 tarihli ve 122 nolu tapu kaydı ve dayanak vergi kaydı tüm tedavülleri ile birlikte tapu sicil müdürlügünden istenerek incelenmeli, gerekirse konusunda uzman olan bilirkişiden rapor alınmall, taşınmaz başında keşif yapılarak resen tespit edilecek mahalli bilirkişiler ve hayatta olmaları halinde tutanak bilirkişileri ile dava konusu taşınmazın diğer hissedarlarının veya mirasçılarınin resen bilgisine başvurulmal, davactya delillerini bildirmesi için usulüne uygun süre verilerek bildirmesi halinde delilleri toplanmal, TMK.nun 594. maddesinde belirtilen ilanlar yapılmalı ve dosya içerigindeki deliller birlikte incelenerek davacının davasın ispat edip etmediği duraksaması belirlenmelidir. Mahkemece eksik araştırma ile karar verilmesi doğru görülmemiş, bu sebeple hükmün bozulmasina karar verilmiştir." Yargıtay 14. Hukuk Dairesi, E: 2016/11753,K: 2019/4699, T: 23.05.2019 (UYAP).

Nar, s. 48. 


\section{talebi hakkında araştırma yapılmasını işaret etmiştir. ${ }^{59}$ Kanaatimce, üç kısımdan} oluşan terditli davada, öncelikle muris muvazaası hukuksal nedenine dayalı tapu iptali ve tescil davası karara bağlanmalıdır. Zira, bu davada verilecek kabul kararı ile dava konusu taşınmaz mirasçların yasal miras payları oranında tapu siciline tescil edileceğinden dolayı, gereksiz tenkis hesaplaması yapılması, usul ekonomisi ve her üç hukuk müessesenin konuluş amaçlarına aykırılık oluşturacaktır.

\section{Süre}

Miras sebebiyle istihkak davasına ilişkin süreler, tenkis davasından farklıdır. Miras sebebiyle istihkak davasında birden fazla süre bulunur. Ayrıca davalının iyiniyetli olması ya da olmaması, süreler için belirleyicidir. TMK md.639/1'e göre, "miras sebebiyle istihkak davası, davacının kendisinin mirasçı olduğunu ve iyiniyetli davalının terekeyi veya tereke malın elinde bulundurduğunu öğrendiği tarihten başlayarak bir yll ve her halde mirasbırakanın ölümünün veya vasiyetnamenin

59 "... tenkis (indirim) davası, miras bırakanın saklı payları zedeleyen ölüme bağlı veya sağlar arası kazandırmaların (bă̆lş) yasal sınıra çekilmesini amaçlayan, öncesine etkili, yenilik doğurucu (inşai) davalardandır. Tenkis davasının dinlenebilmesi için öncelikli koşul; mirasbırakanın ölüme bağll veya sağlar arası bir kazandırma işlemi ile saklı pay sahiplerinin haklarını zedelemiş olmasıdır. Sakl payların zedelendiğinden söz edilmesi ise kazandırma konusu tereke ile kazandırma (temlik) dışı terekenin tümüyle bilinmesiyle mümkündür. Tereke mirasbırakanın ölüm tarihinde bırakmış olduğu malvarlı̆̆ klymetleri ile iadeye ve tenkise tabi olarak yaptığı kazandırmalardır. Bunlar terekenin aktifini oluşturur. Mirasbırakanın borçları, bakmakla yükümlü olduğu kişilerin 743 sayılı Kanun uygulanacaksa bir aylık 4721 sayılı Kanun uygulanacaksa üç aylık nafakasl, terekenin defterinin tutulmasl, mühürlenmesi, cenaze masraflarl gibi giderler de pasifidir. Aktiften belirtilen borçların indirilmesi net terekeyi oluşturur. Tereke bu şekilde tesbit edildikten sonra mirasın açıldiğ tarihteki fiyatlara göre değerlendirilmesi yapllarak parasal olarak miktarının tespiti gerekir (TMK m.564). Mirasbırakanın TMK'nin 506. maddesinde belirlenen sakl paya tecavüz edip etmediği bulunan bu rakam üzerinden hesaplanır. Tasarruf oranı aşılmış ise tasarrufun niteliğine göre icap ederse kazandırma işleminde, sakl payları zedeleme kastının bulunup bulunmadı̆̆ objektif (nesnel) ve sübjektif (öznel) unsurlar dikkate alınarak belirlenmelidir. Zira tasarruf oranın aşan her kazandırmada saklı payları zedeleme kastının varlığından söz edilemez.

Mutlak olarak tenkise tabi tasarruflarda (ölüme bağll tasarruflar veya TMK'nin 565. maddesinin 1, 2 ve 3 bentlerinde gösterilenler) veya sakl payın ihlal kastının varlığı kesin olarak anlaşılan diğerlerinde özellikle muayyen mal hakkında tenkis uygulanirken TMK'nin 570. maddesindeki stralamaya dikkat etmek davalı mahfuz hisseli mirasçllardan ise aynı Kanunun 561. maddesinde yer alan mahfuz hisseden fazla olarak alınanla sorumluluk ilkesini gözetmek, dava konusu olup olmadiğına baklmayarak önce ölüme bağlı tasarruflarla davacının saklı payını tamamlamak, sonra sağlar arası tasarrufları dikkate almak gerekir. Bu işlem sırasında dava edilmeyen kişi veya tasarrufların tenkisi gerekeceği sonucu çıkarsa davacının onlardaki hakkını dava etmemesinin davaltyı etkilemeyeceği ve birden çok kişiye yapılan teberru tenkise tabi olursa 563. maddede yer alan, alınanla mütenasip sorumluluk kural gözetilmelidir.

Davalıya yapılan tasarrufun tenkisine sıra geldiği takdirde tasarrufun tümünün değeri ile davalıya yapılan fazla teberru arasında kurulan oranda (Sabit Tenkis Oranı) tasarrufa konu malın paylaşılmasının mümkün olup olamayacă̆ (TMK m.564) araştırılmalıdır. Bu araştırma sonunda tasarrufa konu mal sabit tenkis oranında bölünebilirse bu kısımların bağımsız bölüm halinde taraflar adına tesciline karar verilmelidir.

Tasarrufa konu malın sabit tenkis oranında bölünmezliği ortaya çıktığı takdirde sözü geçen 564. maddedeki tercih hakk gündeme gelecektir. Böyle bir durum ortaya çıkmadan davalının tercih hakkı doğmadan davallnın tercihini kullanması söz konusu olamaz. Daha önce bir tercihten söz edilmişse sonuç doğurmaz. O zaman davalıdan tercihi sorulmak ve 11.11.1994 günlü 4/4 sayll Içtihadı Birleştirme Kararı uyarınca süratle dava konusu olup sabit tenkis oranına göre bölünemeyen malın, karar tarihindeki rayice göre değeri belirlenmeli ve bu değerin sabit tenkis oranıla çarpımından bulunacak nakdin ödetilmesine karar verilmelidir." Yargitay 1. Hukuk Dairesi, E: 2016/9779, K: 2019/3469, T: 29.05.2019(UYAP). 
açılmasının üzerinden on yıl geçmekle zamanaşımına uğrar." TMK md. 639/2'ye göre, "iyiniyetli olmayanlara karşı zamanaşımı süresi yirmi yıldır." Miras sebebiyle istihkak davasına ilişkin öngörülen sürelerin hukuki niteliği, zamanaşımı ${ }^{60}$ niteliğinde olup, tenkis davasına ilişkin süreler hak düşürücü süre niteliğindedir. ${ }^{61}$

\section{IV. ÖLÜME BAĞLI TASARRUFLARIN IPTALI DAVASI İLE KARŞILAŞTIRMA}

\section{A. GENEL OLARAK ÖLÜME BAĞLI TASARRUFLARIN IPTALİ} DAVASI

Ölüme bağlı tasarruflar, TMK'nın " Miras Hukuku" başlıklı Üçüncü Kitabının "Mirasçılar" başlıklı birinci kısmında " Ölüme Bağlı Tasarruflar " başlıklı ikinci bölümde düzenlenmiştir. Ölüme bağlı tasarruflar özünde sağlar arası hukuki işlemler gibi birer hukuki işlemdir. Bu nedenle bu tasarrufların bazı geçerlilik koşullarını taşıması gerekir. ${ }^{62}$ Hukuki işlemlerde görülecek geçersizlik haller, yokluk, butlan ( kesin hükümsüzlük), iptal edilebilirlik, tek taraflı bağlamazlık ve eksiklik olarak sayılabilir. Ölüme bağlı tasarrufların da aynı esaslar bağlamında değerlendirilmesi mümkündür. ${ }^{63}$ Ölüme bağlı tasarrufun kurucu unsurları noksansa, bu tasarruf kendiliğinden ( eo ipso ) hükümsüz kalır. Özellikle ölüme bağlı tasarrufta bulunma iradesinin ( animus testandi'nin) eksik olduğu durumlar, hükümsüzlüğe örnektir. ${ }^{64}$ Ancak hukuki işlemler, hata, hile, korkutma gibi bir nedenle sakatlanmışsa, iradesi sakatlanan kişi, işlemin iptalini TBK m. 39 hükmünde belirtilen süre içinde talep edebilir. Belirtilen sürede bu hak kullanılmadığ 1 takdirde, işlem geçerli olur. Bu maddeye göre, "Yanılma veya aldatma sebebiyle ya da korkutulma sonucunda sözleşme yapan taraf, yanılma veya aldatmayı öğrendiği ya da korkutmanın etkisinin ortadan kalktı̆̆ı andan başlayarak bir yıl içinde sözleşme ile bağl olmadiğını bildirmez veya verdiği şeyi geri istemezse, sözleşmeyi onamış sayılır. Aldatma veya korkutmadan dolayı bağlayııılı̆̆ı olmayan bir sözleşmenin onanmış saylması, tazminat hakkını ortadan kaldırmaz."

Ölüme bağlı tasarrufların iptali ise, mahkeme kararı ile mümkündür. ${ }^{65}$ Ölüme bağlı tasarruflarda, mirasbırakanın son arzularının yerine getirilmesi

60 Gençcan, s. 1212; Kaçak, s. 367; Eren, s. 1057 (İstihkak).

61 Özuğur, s. 1482; Dural / Öz, s. 286; Öztan, s. 432; Nar, s. 49; Gençcan, s. 629; Öztürkler, s. 109; Serozan / Engin, s. 555; Ayan, s. 315; " Talep alacak niteliğinde ise, bu süreyi zamanaşım süresi olarak görebiliriz. ... Talep ayni bir talep ise, bu süreleri 'zamanaşımı' süresi olarak nitelemek; Türk Hukuku'nda ayni taleplerin ve davaların zamanaşımı süresine bağlı olmayacağı genel kabulü ile bağdaşmamaktadır" Hatemi, s. 173.

62 Ruhi / Ruhi, s. 13.

63 Ayan, s. 157.

64 Serozan / Engin, s. 439.

65 İmre / Erman, s. 205; Oral, s. 75; Nar, s. 50; Hatemi, s. 138; Öztan, s. 232; Güneri, Cemal (2018) Ölüme Bağlı Tasarrufların İptali, Ankara, Seçkin, s. 82. 
amaçladığından, ölüme bağlı bir tasarruf hata, hile, korkutma gibi bir nedenle sakat olsa bile, dava açılmaması durumunda geçerli olduğu kabul edilmiştir. Ölüme bağlı tasarrufları, mümkün oldukça mirasbırakanın iradesi doğrultusunda ayakta tutmak gerekir. ${ }^{66} \mathrm{Bu}$ nedenle ölüme bağlı tasarruf, yalnızca mirasçı veya vasiyet alacaklısının iptali talep ve dava etmesi üzerine, mahkeme tarafından iptal kararı verilebilir. ${ }^{67}$

TMK m. 557 hükmüne göre, ölüme bağlı tasarrufların iptal sebepleri "tasarruf yapanın ehliyetsizliği, hukuka, ahlak ve adaba aykırıllk, şekil eksikliği, hata, hile ve tehdit” olarak sayılmıştır. Yargıtay'a göre, ölüme bağlı tasarrufun iptali davasının sebepleri sınırlıdır. ${ }^{68} \mathrm{Bu}$ hallerde, davacıya sadece ölüme bağlı tasarrufun iptali davası açma hakkı tanınarak, iptalin ancak mahkeme kararı ile söz konusu olduğu belirtilmiştir. ${ }^{69}$ Mirasbırakanın irade bozukluğu ile yaptığ ölüme bağlı tasarruftan, bir yıllık hak düşürücü süre içinde dönmemişse, artık ölümünden sonra onun mirasçıları iptal davası açamaz. ${ }^{70}$ Yargıtay, mirastan feragat sözleşmesinin, TBK’nın m. 27 hükmüne göre, kanunun emredici hükümlerine, ahlaka, kamu düzenine, kişilik haklarına aykırı veya konusu imkansız olması halinde sözleşmenin kesin olarak hükümsüz olacağından dolayı, davanın hak düşürücü süreye tabi olmadığına isabetle karar vermiştir. ${ }^{71}$

66 Ruhi / Ruhi, s. 14.

67 İmre / Erman, s. 205; Oral, s. 75; Nar, s. 50; Hatemi, s. 138; Özuğur, s. 1209.

68 "MK.557.maddesi iptal nedenlerini sinırlamıştır. Kural olarak anılan hüküm dışında bir nedenle vasiyetnamenin iptali istenemez ve hakim bu nedenlerle bağlıdır. Bu bakımdan vasiyet alacaklısının miras birakandan önce ölmesi olgusuna dayantlarak vasiyetnamenin iptali istenemez. Bu husus vasiyetname alacaklisl tarafindan açılan vasiyetnamenin tenfizi davasında itiraz olarak ileri sürülebilir. O halde mahkemece, davanın hukuki yarar yokluğu nedeniyle reddine karar verilmesi gerekirken davanın kabulüne karar verilmesi doğru görülmemiştir." Yargitay 3. Hukuk Dairesi, E: 2010/19745, K: 2011/2854, T: 28.02.2011 (UYAP).

69 Oral, s. 82; Kılıçoğlu, s. 192; İnan / Ertaş / Albaş, s. 312; Antalya, s. 245; Günay, Erhan (2016) Miras Hukukunda Ölüme Bağlı Tasarrufların İptali Davaları, Ankara, Seçkin, s. 133; Ayrıntılı bir çalışma için Bakınız. Başara, Gamze Turan (2009) Ölüme Bağlı Tasarrufların Hükümsüzlüğü, $\quad$ Ankara, Turhan Yayınevi, s. 31; İnal, s. 325; Ruhi / Ruhi, s. 43.

70 Gençcan, s. 495.

71 "Dava, TBK'nun 27.maddesi uyarınca kesin hükümsüzlük ve yine TBK'nun 30 ve devamı maddelerinde yer alan irade bozukluklarına dayalı olarak açılan mirastan feragat sözleşmesinin iptaline, olmadiğl taktirde TMK'nun 506 ve devamı maddelerine göre tenkise veya feragat karşılı̆̆ olarak alınan $100 \quad$ TL'nin geri verilerek miras paylaşımına katılmaya karar verilmesine ilişkindir. Mahkemece, sadece TBK'nun 30 ve devamı maddelerinde yer alan hukuki sebepler yönünden değerlendirme yapılarak TBK'nun 39.maddesinde yer alan 1 ylllık hak düşürücü sürenin geçtiği gerekçesiyle davanın reddine karar verilmiştir. TBK'nun 27.maddesinde yer alan kesin hükümsüzlük bakımından herhangi bir araştırma ve incelemenin yapılmadığ belirlenmiştir. Eski BK'nun 20.maddesinde yer alan “ akdin mevzuunun gayri mümkün veya gayri muhik yahut ahlaka (adaba) mugayir olması” durumlarına ilişkin herhangi bir incelemenin yapılmadiğı saptanmıştır. 6098 sayll TBK'nun 27.maddesine göre kanunun emredici hükümlerine, ahlaka, kamu düzenine, kişilik haklarına aykırı veya konusu imkansız olan sözleşmeler kesin olarak hükümsüzdür. Aynı maddenin ikinci fikrasına göre de, sözleşmenin içerdiği hükümlerden bir kısmının hükümsüz olmast, diğerlerinin geçerliliğini etkilemez, ancak bu hükümler olmaksızın sözleşmenin yapılamayacağı açıkça anlaşılırsa sözleşmenin tamamı kesin olarak hükümsüz olur, denilmektedir. O halde mahkemece eski BK'nun 20 ve yeni TBK'nun 27.maddelerinin kapsamlarl göz önünde bulundurularak ve bu maddede yer alan hükmün herhangi bir hak 
Öğretide, TMK m. 557'de yer alan zorlamanın ( maddi cebrin ) tehditle birlikte aynı hukuksal potada eritilmesi ve iptal yaptırımına bağlanması haklı olarak eleştirilmiş ve zorlamanın her zaman kendiliğinden hükümsüz olması gerektiği belirtilmiştir. ${ }^{72}$ Ancak başka bir görüşe göre, TMK'nın 504/1 ve 557/2 maddesinde yer alan "zorlama" ibaresini " maddi cebir düzeyine ulaşmamış fiziksel zorlama" şeklinde anlaşılmasını belirten düşüncede isabet bulunmaktadır. Bu görüşe göre, kafasına silah dayanmış birisinin ölüme bağlı tasarruf yapmaya zorlanmasında olduğu gibi, maddi cebir altında tasarrufta bulunan iradesi tümüyle ortadan kaldırıldığından dolayı, tasarrufun yok sayılması gerektiği ${ }^{73}$ isabetle belirtilmiştir. Zira, kafasına silah dayanmış bir kişinin iradesinden söz edilemez. Bu nedenle, sözleşmenin kurucu unsurlarını oluşturan karşılıklı ve birbirine uygun irade beyanlarının bulunmaması halinde, sözleşme ilişkisi kurulamaz. Bir sözleşmenin yokluğu ( inexistance ) ilgili herkes tarafından, her zaman ileri sürülebilir. Hakim, bu hususu yargılama sırasında res'en göz önüne almak zorundadır. ${ }^{74}$ Ancak bu gibi durumlarda açılacak bir menfi tespit davası ile, ölüme bağlı tasarrufun hiç meydana gelmediği veya baştan itibaren hükümsüz hale geldiği yahut sonradan hükümsüz kaldığ 1 mahkemece hüküm altına alınabilir. ${ }^{75}$ Yargıtay ise, TMK'nın m. 557 hükmünde sayılan sebeplerin bulunması halinde, vasiyetnamenin iptal edileceğini, ancak bu sebepler dışında kalan durumlara dayanılarak ölüme bağlı tasarrufun iptalini istenilemez ise de, koşullarının varlığı durumunda tenkis talebine konu edileceğini belirtmiştir. ${ }^{76}$

düşürücü süreye tabi olmadığı gözetilerek, her türlü delille kanıtlanmasinin mümkün olduğu göz önünde bulundurularak iddia ve savunma doğrultusunda gerekli araştırma ve incelemenin yaplması ondan sonra uyuşmazllk hakkinda olumlu ve olumsuz bir karar verilmesi gerekirken bu husus göz ardl edilerek ve eksik incelemeye dayalı olarak hüküm kurulmuş bulunması usul ve yasaya aykirıdır." Yargitay 8. Hukuk Dairesi, E: 2013/19308, K: 2014/11767, T: 06.06.2014 (UYAP).

72 Serozan / Engin, s. 439.

73 Ayan, s. 166; Başara, s. 67 (Hükümsüzlük); Güneri, s. 121.

74 Oğuzman, M. Kemal / Öz, Turgut (2015) Borçlar Hukuku Genel Hükümler, C: 1, 13. Bası, İstanbul, Vedat Kitap̧̧ıllık, s. 174.

75 Kocayusufpaşaoğlu, s. 349.

76 "....TMK'nın 557'nci maddesinde vasiyetnamenin iptali sebepleri sinırl olarak saylmış olup, bunlar; 1Ehliyetsizlik, 2- Vasiyetnamenin yanılma, aldatma, korkutma veya zorlama sonucunda yapılmış olması, 3Tasarrufun içeriğinin bağlandlğı koşullar veya yüklemelerin hukuka veya ahlâka aykir olması, 4- Tasarrufun kanunda öngörülen şekillere uyulmadan yapılmış olması hâlleridir. TMK'nın 557'nci maddesinde sayılan sebeplerin bulunması hâlinde vasiyetnamenin iptali gerekir. Bu sebepler dışında kalan durumlara dayanılarak ölüme bağlı tasarrufun iptali istenilemez ise de, koșullarının varlığ durumunda tenkis talebine konu edilebilir (TMK. m. 560-562).

Tenkis, indirme, azaltma veya eksiltme anlamina gelmektedir. TMK'nın 560 'ınc maddesi ve devamı hükümlerinde düzenleme alanı bulan tenkis davası ise, miras birakanın, saklı payı ihlâl eden sağlar arası veya ölüme bağll kazandırmalarının, yasal sinıra indirilmesini sağlayan yenilik doğurucu nitelikte bir davadır (Nar, A.: Türk Miras Hukukunda Tenkis, On İki Levha Yayınları, İstanbul 2016, s.14 vd.). Söz konusu hükümden de anlaşılacağı üzere, tenkis davasının konusu, miras bırakanın, sakl payl mirasçı/mirasçılarının sakll payını ihlal eden ölüme bağlı ve sağlar arası tasarruflarıdır. Esasında kural olarak miras birakanın ölüme bağlı ta- 
sarrufları tenkise tabidir. Zira kural olarak miras bırakan, sağlı̆̆ında kendi mal varlı̆̆ değerleri üzerinde dilediği gibi tasarrufta bulunma özgürlügüne sahiptir. Her özgürlükte olduğu gibi, burada da miras bırakanın sınırsız bir özgürlüğ̈̈ yoktur. Bu nedenle TMK'nın 565 'inci maddesinde dört bent hâlinde miras bırakanın tenkise tabi sağlar arası tasarrufları belirlenmiştir. Bir diğer anlatımla, miras bırakan sağlı̆̆ında kendi mal varlı̆̆ de ğerleri üzerinde dilediği gibi tasarrufta bulunabilir. Ancak bu sağlar arası tasarruflar, TMK'nın 565 'inci maddesi kapsamındaki tasarruflar kapsamında ise, bu durumda ölüme bağll tasarruflar gibi tenkise tabi olacaklardir.

Miras birakanin sakl payı ihlal eden bir tek tasarrufu varsa, ihlal edilen sakl pay miktarı bulunur ve bu oranda tenkis yapılır. Ancak tenkise tabi birden fazla kazandırma varsa, tenkiste strayı düzenleyen

TMK'nın 570'inci maddesi hükmü gereğince tenkis yapılacaktır. Buna göre tenkis, sakl pay tamamlanıncaya kadar önce ölüme bağll tasarruflardan, bu yetmezse, en yeni tarihlisinden en eski tarihlisine doğru geriye gidilmek suretiyle sağlar arası kazandırmalardan yapılır. Ölüme bağlı kazandırmaların aksine, miras bırakanın yaptı̆̆ sağlar arası kazandırıcı hukuki işlemler kayıtsız,

koşulsuz tenkise tabi tutulmamıştır. Burada işlemin tenkise tabi tutulabilmesi için ön koşul; saklı paya el atma, tasarruf edilebilirlik sınır-nın aşılmasıdır. Ancak bu da yeterli değildir. Sağlar arası kazandırmaların tenkise tabi tutulabilmesi için saklı paya el atma yanında TMK'nın 565 'inci ve 567'nci maddelerinde açılanan koşulların da gerçekleşmesi gerekmektedir.

Medeni hukuk yargllamasına hâkim olan ilkelerden biri de taleple bağlllık ilkesidir. Bu ilke HMK'nın 26'ncı maddesinde açıça ifade edilmiştir. Buna göre, hâkim tarafların talepleri ile bağlıdır. Kanunlarda gösterilen sinırl sayıdaki istisnalar bir kenara bıraklacak olursa talepten fazlasına veya talepten başka bir şeye karar veremez. Fakat hâkimin duruma göre talep sonucundan daha azına karar vermesinin önünde engel yoktur. Taleple bağlılık ilkesi özü itibariyle hâkimin, tarafların talebiyle bağlı olduğunu ifade eder. Taleple bağlılık ilkesinin taşıdı̆̆ ilk anlam; tarafin talep etmediği husus hakkında mahkemenin karar veremeyeceğidir. Buna göre tarafin neyi talep edip etmediği ve hâkimin ne hakkında karar verip veremeyeceği dava dilekçesine baklarak tespit edilir. Bu tespitin konusunu, istenilen hukuki sonuç oluşturur. Bu itibarla hâkimin karar verme sınırı dava dilekçesi ile belirlenmiş olur. Taleple bağlllık ilkesinin taşıdığ ikinci anlam ise tarafin talebinden fazlasina mahkemece karar verilememesidir (HMK. m.26). Taleple bă̆lllk ilkesine yüklenen bu anlam ayn zamanda 24'üncü maddede ifade edilen "tasarruf ilkesi" ve 25 'inci maddesinde yer alan "taraflarca getirilme ilkesi" ile de bağlantılıdır. Nihayet taleple bağlllı ilkesinin bir diğer anlamı ise hâkimin talep edilenin dışında, farklı bir şeye karar verememesidir. Talep edilenden farklı bir şeye karar verememe, dilekçenin talep sonucu kısmı ile verilen hükmün sonuç kısmının karşılaştırılması suretiyle tespit edilir.

Uygulamada somut vakalara dayanmadan davaların açılıp yürütülmesinin önüne geçmek amacıyla HMK'da yeni bir düzenleme yapılmış ve 194 'üncü maddenin birinci fikrasında "Taraflar, dayandıklarl vakaları, ispata elverişli şekilde somutlaştırmalıdırlar." hükmüne yer verilmiştir. Aynı maddenin ikinci fikrasında ise somutlaştırma yükünün delillerle ilişkisi ortaya konulmuş ve tarafların, dayandıkları delilleri ve hangi delilin hangi vakıanın ispatı için gösterildiğini açıkça belirtmek zorunda oldukları düzenlenmiştir (HMK. m. 119/2). Diğer taraftan, HMK'da iddia ve savunmanın genişletilmesi veya değiştirilmesi yasağının başlangıcl, cevaba cevap ve ikinci cevap dilekçelerinin verilmesine bağlanmıştır. Bu bakımdan cevaba cevap ve ikinci cevap dilekçeleri, önceki düzenlemeye göre daha önemli hâle gelmiştir. Bu dilekçeler ile taraflar birbirlerinin iddialarını ele alıp çürütmeye veya iddia ve savunmaların haklı bir temele dayanmadığını açıklamaya çalışırlar. Açıtır ki, davacı cevaba cevap dilekçesi ile iddiasını, davalı da ikinci cevap dilekçesi ile savunmasını dilediği gibi değiştirebilir ve genişletebilir. Ancak yazılı yargılama usulünün ilk aşamasını teşkil eden dilekçeler teatisi safhasının tamamlanmast ile taraflar iddia ve savunma sebeplerini diğer bir deyişle davanın temelinin oluşturan maddi vakıaları sınırlamış ve teksif etmiş olur (Postacıoğlu İ. E. I Altay S.: Medeni Usul Hukuku Dersleri, Istanbul 2015, s.474).

İddia ve savunmanın genişletilmesi veya değiştirilmesi yasağının kapsamına iddia ve savunma sebebini oluşturan maddi vakıalar da girdiğinden, bu yasağın yargılamanın hangi aşamasında başladığına ilişkin soruya cevap veren HMK'nın 141 'inci maddesinde yer alan düzenlemeye de değinmek gerekmektedir. Bu hükme göre taraflar, cevaba cevap ve ikinci cevap dilekçeleri ile serbestçe; ön inceleme aşamasında ise ancak karşı tarafin açı muvafakati ile iddia ve savunmalarını genişletebilir yahut değiştirebilirler. Ön inceleme aşamasının tamamlanmasından sonra ise diğer tarafin açık muvafakati ve islah dışında iddia ve savunma genişletilemez yahut değiştirilemez (HMK m. 141/1).

Görüldüğ̈̈ üzere cevaba cevap dilekçesinin verilmesinden sonraki evrede dava ve cevap dilekçelerinde bildirilen maddi vakaaların hem genişletilmesi hem de değiştirilmesi ilke olarak yasaktır. Bu yasağın kapsamına, dava sebebi olarak vakıalar ve talep sonucu dâhildir. Ancak talepten başka bir şeye hüküm verilen hâl- 


\section{Kanaatimizce zorlamanın maddi cebir boyutuna gelmesi halinde mirasbırakanın iradesinden bahsedilememesi sebebiyle, yasal ya da atanmış mirasçıların süreye bağlı kalmaksızın menfi tespit davası açabilecekleri, favor testamenti kuralının da bir gereğidir.}

ler ve kendiliğinden araş̧trma ilkesinin uygulandı̆̆ davalarda davayı genişletme veya değiştirme yasağ uygulanmaz (Pekcanitez H.: Pekcantez Usul Medeni Usul Hukuku, C.II, 15. Basl, Istanbul 2017 , s.1250; Tanrıver, S.:Medeni Usul Hukuku, C.I, Ankara 2016, s.681,682). Bu yasağın istisnaları yine HMK'nın 141 'inci maddesinin son fikrasında açıklanmış ve karşı tarafin açılk muvafakati ya da ıslah suretiyle iddia ve savunmanin genişletilip, değiștirilebileceği kabul edilmiştir.

Dilekçeler teatisinin tamamlanmasından sonra yargılamanin ikinci kesiti olan ön inceleme aşamasina geçilecek, ön inceleme safhasinda da öncelikle dava şartları ve ilk itirazlar incelenecek, uyuşmazllk konuları tam olarak belirlenecek, tarafların delillerinin sunulması ve delillerin toplanması için gereken işlemler yapılacak ve taraflar, üzerinde serbestçe tasarruf edebilecekleri davalarda sulhe teşvik edilerek, bu hususlar tutanağa geçirilecektir (HMK m.137/1; 140/1). Madde metninde de yer alan "uyuşmazllk konularının tam olarak tespiti" ifadesi, yargılama bakımından büyük bir öneme sahiptir. Çünkü taraflar, yukarıda belirtildiği şekilde gerek 119'uncu maddenin birinci fikrasinin (e) ve (f) bentleri ile 129'uncu maddenin birinci fikrasinin (d) ve (e) bentleri gerekse de 194'üncü madde kapsaminda somutlaşttrma yüküne uygun olarak iddia ve savunmaların ileri sürmemişse, hâkimin aydınlatma ödevi çerçevesinde tarafların iddia ve savunmaların somutlaştırması, delilerle vakalar arasındaki bağın kurulması, bu noktada soru sorup açık olmayan noktaları aydınlatması gerekir. Bunun ardından hâkim, uyuşmazllk konularını net ve açık şekilde, tam olarak tespit etmelidir (Pekcanttez, Pekcanttez Usul, s.1288).

Sözü edilen Kanunun 140'ınc maddesinin ü̧̈üncü fikrasinda ise "Ön inceleme duruşmasının sonunda, tarafların sulh veya arabuluculuk faaliyetinden bir sonuç alıp almadlkları, sonuç alamadıkları takdirde anlaşamadıkları hususların nelerden ibaret olduğu tutanakla tespit edilir. Bu tutanağın altı, duruşmada hazır bulunan taraflarca imzalanır. Tahkikat bu tutanak esas alınmak suretiyle yürütülür" (HMK m. 140/3) denilmektedir. Maddeden anlaşıldiğı üzere, ön inceleme aşamasinda tutulan tutanak özel bir öneme sahiptir. Zira uyuşmazllk konuları çözümlenmişse bu tutanak bir sulh belgesi olarak kabul edilecek; uyuşmazllk devam edecekse tutanakta yer almayan hususlar tahkikatı konusunu oluşturmayacak, diğer bir ifadeyle hükme esas alınmayacaktır. Tahkikat aşamasında ise tarafların ileri sürdükleri vakaların doğru olup olmadı̆̆ araştırılıp tespit edilerek uyuşmazlık konularının gerçekliği çerçevesinde hüküm oluşturulacaktır (Pekcanttez, Pekcanıtez Usul, s.1232,1233).

Bu genel açıllamaların ışı̆ı̆nda somut olaya bakıldı̆̆ında; mahkemece vasiyetnamenin iptali isteminin reddine karar verildiği, dava dilekçesi incelendiğinde dava konusunun "05.07.2005 günlü Z..... Noterliğinin ..... Y. Nolu vasiyetmesinin iptali ile vasiyete konu taşınmazın tüm varisler adına tescili istemi", talep sonucunun "vasiyetnamenin iptaline ve vasiyete konu taşımmazlartn tüm varisler adına tesciline..." ilişsin olduğu, "açıklamalar" başlıkl paragrafinda sadece "..vasiyetnamenin tasarruf nisabını aşmıştır. Hukuka aykirldır. Bu nedenle iptal edilmelidir." şeklindeki açlklamalara yer verildiği, ön inceleme duruşmasında ise tenkis istemine ilişkin bir beyanı bulunmadığ ve bir başka ifade ile somutlaştırma yükümlügünün yerine getirilmediğinin anlaşıldığı, davanın reddine ilişkin ilk kararın temyiz dilekçesinde de ölüme bağgl tasarrufun tenkisini talep ettikleri hâlde bu talepleri hakknda bir karar verilmediğine dair temyiz istemi bulunmamaktadir. Tüm bu hususlar birlikte değerlendirildiğinde; davacının isteminin sadece vasiyetnamenin iptaline ilişkin olduğu, dava dilekçesinde tasarruf nisabindan bahsedilmesinin sebebinin nisabı aşan tasarruf nedeniyle vasiyetnamenin hukuka aykir olduğunu dile getirmek olduğu böyle olunca yerel mahkemenin yazıll şekilde karar vermesinde bir isabetsizlik bulunmamaktadır.Hukuk Genel Kurulunda yapılan görüşmeler S sırasında davacıların dava dilekçesinde tasarruf nisabının aşllması nedeniyle vasiyetnamenin iptalini $\quad$ talep ettikleri, TMK'da tasarruf nisabının aşılmasının ölüme bağlı tasarrufların iptal sebebi olarak değil de tenkis davası açılarak ya da savunma yoluyla ileri sürülebileceği hususu dikkate alındığında, davacının vasiyetnamenin iptali istemi yaninda tenkis talebinin de bulunduğunu kabul eden Özel Daire bozma kararınin yerinde olduğu ve bu sebeple yerel mahkeme kararının bozulmast gerektiği görüşü ileri sürülmüss ise de bu görüss yukarıda açılklanan nedenlerle Kurul çoğunluğu tarafindan kabul edilmemiştir. Bu nedenle usul ve yasaya uygun direnme kararının onanmast gerekmiştir." Yargitay Hukuk Genel Kurulu, E: 2017/3-1017,K: 2018/1750, T: 20.11.2018 (UYAP). 


\section{B. TENKISS DAVASI İLE ÖLÜME BAĞLI TASARRUFLARIN İPTALİ DAVASI ARASINDAKİ FARKLILIKLAR}

\section{Konu ve Amaç}

Tenkis davasıyla saklı paylı mirasçının saklı payını korumak, iptal davasıyla da, iradi ya da yasal mirasçıların, mirasçı olmalarından kaynaklanan haklarının korunması amaçlanır. ${ }^{77}$ Tenkis davası mirasbırakanın hem ölüme bağlı hem de sağlararası tasarruflarını konu edinirken, iptal davası sadece ölüme bağlı tasarrufları konu edinir. İptal davasında, ölüme bağlı tasarrufun tamamen hükümsüz hale gelmesi, tenkis davasında ise, saklı pay ihlalini gidermek için saklı payı ihlal eden kısmın hükümsüz hale gelmesi talep edilir. ${ }^{78}$ Öğretideki hakim görüşe göre, tenkis kararı gibi iptal kararı da nispi karakterli olup, davacı ve davalı kişiler hakkında hüküm doğurur. Bu nedenle, ehliyetsizlik ya da şekil noksanlığı gibi ölüme bağlı tasarrufun tamamını sakatlayan iptal sebebi bulunsa bile aleyhine iptal davası açlmamış kişiler yönünden ölüme bağlı tasarruf geçerliliğini korur. ${ }^{79}$

\section{Taraflar}

Tenkis davasının davacıları, TMK m. 560/1, 562 hükümlerine göre, saklı paylı mirasçılar ile bazı hallerde saklı paylı mirasçıların alacaklıları ya da iflas idaresidir. Buna karşın iptal davası açma hakkına sahip kişiler ise, TMK md.558/1'e göre, mirasçların tamamı hatta koşulların gerçekleşmesi halinde vasiyet alacaklılarıdır. Bu nedenle iptal davasının davacıları, tenkis davasının davacılarına göre daha fazladır. ${ }^{80}$ Tenkis davasının davalısı, mirasbırakan tarafından lehine tenkise tabi kazandırma yapılan kişidir. İptal davasında ise, iptal sebebiyle sakatlanmış olan ölüme bağlı tasarrufla miras hukukuna ilişkin bir menfaat sağlayan kişi davalidır. ${ }^{81}$

\section{Süre}

TMK'nda, tenkis davasının açlabilmesi için , bir ve on yıllık iki farklı hak düşürücü süre düzenlenmiştir. İptal davası açma süresi açısından ise, bir, on ve yirmi olmak üzere üç ayrı hak düşürücü süre düzenlenmiştir. TMK md.559/1'e göre; "İptal davası açma hakkı, davacının tasarrufu, iptal sebebini ve kendisinin

\footnotetext{
Nar, s. 53; Tüfek, s. 107.

İmre / Erman, s. 216; Nar, s. 53; Tüfek, s. 107.

Nar, s. 55; Dural / Öz, s. 224; İmre / Erman, s. 225; Ayan, s. 157; Öztan, s. 232; Özuğur, s. 1246.

Nar, s. 53; Kılıçoğlu, s. 197; Özuğur, s. 1211; İnan / Ertaş / Albaş, s. 313; Öztan, s. 232; Gençcan, s. 495; Antalya, s. 256; Başara, s. 102 (Hükümsüzlük); Güneri, s. 160; Günay, s. 146.

81 Dural / Öz, s. 225; Nar, s. 54; Ayan, s. 167; Antalya, s. 256; Başara, s. 101 (Hükümsüzlük); $\quad$ Güneri,
} s. 162; Ruhi / Ruhi, s. 45. 
hak sahibi olduğunu öğrendiği tarihten başlayarak bir yll ve her halde vasiyetnamelerde açılma tarihinin, diğer tasarruflarda mirasın geçmesi tarihinin üzerinden iyiniyetli davalılara karşı on yıl, iyiniyetli olmayan davalılara karşı yirmi yıl geçmekle düşer." denilmiştir. Yirmi yıllık süre de, on yıllık sürenin işlemeye başladığ tarihte işlemeye başlar. Kötüniyetli olanlara karşı , vasiyetnamelerde açlma tarihi, diğer tasarruflarda mirasın açılması tarihinden itibaren yirmi yıl içinde iptal davası açılabilir. ${ }^{82}$ TMK md. 559/2'ye göre, iptal davasında davacı olabilecekler, tenkis davasında olduğu gibi herhangi bir süreyle sınırlı olmadan bir defi hakkını kullanabilirler. $^{83}$

\section{SONUÇ}

Mirasbırakan sağlığında, belli şartlara uymak koşuluyla istediği gibi tasarrufta bulunabilir. Türk Miras Hukukunda, ailenin korunması ve yasal mirasçlık, miras bırakanın tasarruf özgürlüğü ile ölüme bağlı tasarruf yapmak isteğine göre öncelikli görülmüştür. Mirasbırakanın yaptığı bazı ölüme bağlı ve sağlararası kazandırmaların, saklı payları ihlal ettikleri ya da tasarruf oranını aştıkları oranda etkisizleştirilmeleri, eğer henüz ifa edilmemişlerse, mirasçıların bunları ifa borcundan kurtulması ve şayet ifa edilmişlerse bu oranda iadelerini sağlayan yenilik doğurucu nitelikteki davaya, tenkis davası denilmektedir.

Tenkis davası, saklı payın yaptırımıdır. Mirasta denkleştirme ise, mirasbırakanın mirasçılara yaptığı sağlararası karşılıksız kazandırmalar sebebiyle, mirasçllar arasında eşitliği sağlayan bir kurumdur. Denkleştirmede mirasçı, eşitliğin sağlanması amacıyla aldığı değerleri terekeye iade etmektedir. Miras sebebiyle istihkak davası , dava konusu edilen şey zilyedinden alınarak tamamen geri verilmesini konu edinen bir eda davasıdır. Bu dava ile davalı, davacıya karşı bir tereke konusu hak ve malları verme borcu altına girmektedir.

Tenkis davası mirasbırakanın hem ölüme bağlı hem de sağlararası tasarruflarını konu edinirken, iptal davası sadece ölüme bağlı tasarrufları konu edinir.

\footnotetext{
82 Nar, s. 56; Ayan, s. 168; Hatemi, s. 139; Özuğur, s. 124: Öztan, s. 234; Antalya, s. 247; Başara, s. 104 (Hükümsüzlük ); Gençcan, s. 516; Güneri, s. 169; Günay, s. 151; Kaçak, s. 152; Ruhi / Ruhi, s. 46.

83 İnan / Ertaş / Albaş, s. 320; Ruhi / Ruhi, s. 46; Hatemi, s. 142; Özuğur, s. 1245; Sarı, s. 97; Nar, s. 56; Dural / Öz, s. 287; Öztan, s. 235; Başara, s. 107 (Hükümsüzlük); Gençcan, s. 516; Güneri, $\quad$ s. 172; Günay, s. 151; Kaçak, s. 152.
} 
İptal davasında, ölüme bağlı tasarrufun tamamen hükümsüz hale gelmesi, tenkis davasında ise, saklı pay ihlalini gidermek için saklı payı ihlal eden kısmın hükümsüz hale gelmesi talep edilir. 


\section{KAYNAKÇA}

Akbıyık, Cem (2003) Miras Sebebiyle İstihkak Davası, İstanbul, Der Yayıncılık

Antalya, O. Gökhan (2015) Miras Hukuku, 3. Baskı, İstanbul, Legal.

Ayan, Mehmet (2016) Miras Hukuku, 9. Baskı, Ankara, Seçkin.

Aydın Ünver, Tülay (2011) "Miras Bırakanın Yasa Gereği Denkleştirmeye Tabi Olan Kazandırmaları”, Prof. Dr. Şener Akyol’a Armağan, İstanbul, Filiz Kitabevi.

Başara, Gamze Turan (2013) Miras Hukukunda Denkleştirme, Ankara, Turhan Yayınevi. (Miras).

Başara, Gamze Turan (2016) "Ölüme Bağlı Tasarrufların Tenkisi ve Tenkis Davası", Türkiye Adalet Akademisi Dergisi, C: 7, S: 27, s. 365-407. (Tenkis ).

Başara, Gamze Turan (2009) Ölüme Bağlı Tasarrufların Hükümsüzlüğü, Ankara, Turhan Yayınevi. ( Hükümsüzlük).

Bayramoğlu, Necati Şükrü (2013) Türk Medeni Hukukunda Denkleştirme, (Yüksek Lisans), Akdeniz Üniversitesi, Sosyal Bilimler Enstitüsü.

Dural, Mustafa/Öz, Turgut (2015) Türk Özel Hukuku - Cilt IV - Miras Hukuku, 8. Bası, İstanbul, Filiz Kitabevi.

Eren, Fikret (2016) "Miras Sebebiyle İstihkak Davası", Marmara Üniversitesi Hukuk Fakültesi Hukuk Araştırmaları Dergisi, Prof. Dr. Cevdet Yavuz'a Armağan, C: 22, S: 3, s. 1045-1061 (İstihkak).

Eren, Fikret (1973) Türk Medeni Hukukunda Tenkis Davası, Ankara, Ankara Üniversitesi Hukuk Fakültesi Yayınları (Tenkis).

Gençcan, Ömer Uğur (2011) Miras Hukuku, 2. Baskı, Ankara, Yetkin Yayınları.

Göktürk, Hüseyin Avni (1937) Miras Hukuku, Ankara, Devlet Basımevi.

Gönensay, Samim/Birsen, Kemaleddin (1956) Miras Hukuku, İstanbul, Fakülteler Matbaası.

Günay, Erhan (2016) Miras Hukukunda Ölüme Bağlı Tasarrufların İptali Davaları, Ankara, Seçkin.

Güleş, Bedia (2018) "Türk Miras Hukukunda Denkleştirme", Türkiye Barolar Birliği Dergisi, S: 134, s. 355 - 430.

Güneri, Cemal (2018) Ölüme Bağlı Tasarrufların İptali, Ankara, Seçkin.

Hatemi, Hüseyin (2018) Miras Hukuku, 8. Baskı, İstanbul, Onikilevha.

İmre, Zahit/Erman, Hasan (2017) Miras Hukuku, 13. Basım, İstanbul, Der Yayınları.

İnal, Nihat (2016) Miras Davaları, 5. Baskı, Ankara, Bilge.

İnan, Ali Naim/Ertaş, Şeref / Albaş, Hakan (2019) Miras Hukuku, 10. Bası, Ankara, Seçkin Yayınevi.

Kaçak, Nazif (2006) Miras Hukuku, 1. Baskı, Ankara, Seçkin. 
Kazancı, İdil Tuncer/Apaydın, Bahar Öcal (2015) "Mirasçıların Alacaklılarını Koruyan Davalar ile Tasarrufun İptali Davası İlişkisi", İnönü Üniversitesi Hukuk Fakültesi Dergisi Özel Sayı C: 2, s. $775-808$.

Karayalçın, Yaşar (2000) Mirasbırakanın Muvazaası Mı? Tasarruf Özgürlüğü ve Saklı Payın Korunması Mı? Bir Tartışma, Ankara, Turhan Kitabevi.

Kılıçoğlu, Ahmet M. (2018) Miras Hukuku, 9. Bası, Ankara, Turhan Kitabevi.

Kocayusufpaşaoğlu, Necip (1987) Miras Hukuku, 3. Bası, İstanbul, Filiz Kitapevi.

Nar, Ahmet (2016) Türk Miras Hukukunda Tenkis, İstanbul, Oniki Levha Yayıncılık.

Oral, Alkım (2018) " Miras Hukukunda Tenkis Davası", (Yüksek Lisans), Akdeniz Üniversitesi, Sosyal Bilimler Enstitüsü.

Oğuzman, M. Kemal/Öz, Turgut (2015) Borçlar Hukuku Genel Hükümler, C: 1, 13. Bası, İstanbul, Vedat Kitapçllık.

Ozanemre Yayla, Hatice Tolunay (2011) Mirasın Paylaşılması, Ankara, Turhan Kitabevi.

Özdoğan, Nurcihan Dalcı (2017) " Sağlararası Kazandırma Konusu Taşınmazların Tenkisi", İnönü Üniversitesi Hukuk Fakültesi Dergisi, C: 8, S: 7, s. 363 - 393.

Öztan, Bilge (2018) Miras Hukuku, 9. Baskı, Ankara, Turhan Kitabevi.

Öztürkler, Cemal (2004) Mirasta Denkleștirme, Ankara, Seçkin.

Özuğur, Ali İhsan (2016) Miras Hukuku, 4. Baskı, Ankara, Seçkin.

Petek, Hasan (2012) "Miras Sebebiyle İstihkak Davası ile Adi İstihkak Davası Yarışır mı?", Yaşar Üniversitesi Hukuk Fakültesi Dergisi, S: 1, s. 28-34.

Ruhi, Canan / Ruhi, Ahmet Cemal (2015) Ölüme Bağlı Tasarruflar ve İptali, Ankara, Seçkin.

Sarı, Suat (2018) Miras Hukuku, 7. Baskı, İstanbul, Filiz Kitabevi.

Serozan, Rona / Engin, Baki İlkay (2018) Miras Hukuku, 5. Baskı, Ankara, Seçkin.

Tandoğan, Haluk (1995) "Miras Sebebiyle İstihkak Davası", Ankara Üniversitesi Hukuk Fakültesi Dergisi, C: 12, S: 1-2, s. 268-284.

Turanboy, Nuri (2010) Mirasbırakanın Denkleştirme ve Tenkise Bağlı Sağlar Arası Hukuki İşlemleri, Ankara.

Tüfek, K. Gültekin (1977) Miras Hukukunda Tenkis ve İade Davaları, Ankara, Olgaç Matbaası.

Uyar, Talih (1971) "Uygulamada Tereddüt ve İhtilaf Konusu Olan Üç Müessese: Mirasta Tenkis İptal ve İade", Ankara Barosu Dergisi, S: 3, s. 406-419.

Yazar, İbrahim (2017) " Miras Hukukunda Tenkis", Yüksek Lisans Tezi, Kadir Has Üniversitesi, Sosyal Bilimler Enstitüsü.

Yavuz, Cevdet (1985) "Miras Hukukunda Tenkisten Sonra Tenkis Konusu Geri Verme (İade) Yükümlülüğü", İstanbul Üniversitesi Hukuk Fakültesi Dergisi, C: LI. S: 1, s. 261-333.

UYAP (Ulusal Yargı Ağı Projesi) 